\title{
$O$-GENE DETECTION BY ALLELE SPECIFIC AMPLIFICATION IN THE ABO BLOOD GROUP SYSTEM
}

\author{
Takasumi Matsuki, Tamiko Nakasima, and Ken Furukawa \\ Department of Legal Medicine, Gunma University School of Medicine, \\ Showa-machi, Maebashi, Gunma 371, Japan
}

\begin{abstract}
Summary We have constructed a fast and easy method for the detection of $O$-gene in the ABO blood group system. Our method included allele specific amplification using polymerase chain reaction (PCR) and subsequent analysis with polyacrylamide gel electrophoresis (PAGE) and silver staining. $O$-gene product was observed on the gel in 25 DNA samples from group $\mathrm{O}$ phenotype and 20 DNA samples from group $\mathrm{A}$ or B (genotype $A O$ or $B O$ ) persons. No product was found in 10 DNA samples from group AB phenotype.
\end{abstract}

Key Words $\mathrm{ABO}$, blood group, $\mathrm{O}$-gene, allele specific, $\mathrm{PCR}$

\section{INTRODUCTION}

The ABO blood group system is reliable and informative polymorphism for the blood banking, transfusion, personal identification, and paternity test (Race and Sanger, 1975; Salmon et al., 1984). However, we could not distinguish between $A A$ (or $B B$ ) homozygote and $A O$ (or $B O$ ) heterozygote by serologic analysis unless we could use family pedigree data.

Yamamoto et al. (1990a) reported nucleotide sequences of cDNAs that coded synthetic enzymes for ABO blood group phenotypes from human gastric cancer cell lines. Determination of $\mathrm{ABO}$ genotype from peripheral blood leukocytes was first presented by Yamamoto et al. (1990b). Several variations were developed by using PCR-RFLP method (Lee and Chang, 1992), allele specific PCR (AS-PCR) method (Ugozzoli and Wallace, 1992), and PCR-denaturing gradient gel electrophoresis (PCR-DGGE) method (Johnson and Hopkinson, 1992). Yamamoto's method was shown to be accurate in these three years. However, Yamamoto's and other methods mentioned above are complex as discussed later.

Received April 21, 1994; Revised version accepted June 9, 1994. 
We intended to develop a simple and accurate method for the determination of $O$-gene from peripheral blood leukocytes by allele specific PCR and polyacrylamide gel electrophoresis followed by silver nitrate staining.

\section{MATERIALS AND METHODS}

Preparation of DNA. Twenty-five group $\mathrm{O}, 20$ group $\mathrm{A}$ or $\mathrm{B}$ (genotype $A O$ or $B O$ ) and 10 group $\mathrm{AB}$ blood samples from unrelated Japanese were collected as EDTA treated blood. Genotype $A O$ or $B O$ was determined from family pedigree data. Genomic DNAs from these blood samples were extracted by SDS-proteinase K-phenol method (Sambrook et al., 1989) and Chelex-100 method (Hochmeister et al., 1991).

Preparation of primers for $P C R$. Two primers for the detection of $O$-gene on PCR were synthesized by Milligene Cyclone DNA Synthesizer M7500. The synthesized primers were cleaved from the synthesizer columns with fresh $28 \%$ aqueous ammonium, dried up in Eppendorf type tubes by centrifugal vaporizer, and resolubilized in minimum amount of TE buffer containing $10 \mathrm{~mm}$ Tris- $\mathrm{HCl}$, $0.1 \mathrm{~mm}$ EDTA, $\mathrm{pH}$ 7.5. The sequences of the primers were 5'-GAATTCGGATGTCCTCGTGGTA-3' for a sense primer and 5'-AAGCTTGAGCCAGCCAAGGG-3' for an anti-sense primer.

PCR reaction. Reaction mixture contained $10 \mathrm{~mm}$ Tris- $\mathrm{HCl}$ buffer $\mathrm{pH} 9.0$, $1.5 \mathrm{mM} \mathrm{MgCl}_{2}, 50 \mathrm{~mm} \mathrm{KCl}, 0.1 \mathrm{~mm}$ each dNTP, 4 nmol each primer, 5-100 $\mathrm{ng}$ genomic DNA, and 2.5 U Taq DNA polymerase from Pharmacia Biotech, Tokyo. The amount of genomic DNAs purified by Chelex-100 method was 5 to $15 \mathrm{ng}$ and that by SDS-proteinase K-phenol method was 10 to $100 \mathrm{ng}$. Before addition of Taq DNA polymerase to the reaction mixture, the mixture added one drop of mineral oil was stood on boiling water bath for $5 \mathrm{~min}$. After rapidly cooling down the mixture on salted ice, polymerase was added and PCR reaction was started on a programmable multiple temperature controller (Astec PC-700, Fukuoka). Thirty cycles of PCR were carried out under the conditions, denaturation: $95^{\circ} \mathrm{C}, 40 \mathrm{sec}$; annealing: $56^{\circ} \mathrm{C}, 40 \mathrm{sec}$; extension: $72^{\circ} \mathrm{C}, 30 \mathrm{sec}$ adding one sec on the extension phase in each cycle. The PCR products were stored in a freezer before use.

Detection of PCR product. Five microliters of the PCR product were mixed with $2 \mu \mathrm{l}$ of $50 \%$ glycerol, $0.1 \%$ bromophenol blue (BPB) and $0.1 \%$ xylene cyanol FF (XC) solution. The mixtures were electrophoresed on $15 \%$ polyacrylamide gel sized $8 \mathrm{~cm} \times 7 \mathrm{~cm}$ with TBE-buffer containing $50 \mathrm{~mm}$ Tris, $48.5 \mathrm{~mm}$ borate, and $1 \mathrm{mM} \mathrm{Na} \mathrm{NDTA}_{3}$, and under 5-7 $\mathrm{mA}$ constant currency at room temperature until BPB came at the front of the gel. After electrophoresis, the gel was stained with silver nitrate by the method of Budowle et al. (1991). 


\section{RESULTS}

$O$-gene product from all DNAs of the group O phenotype was stained on polyacrylamide gel at the same electrophoretic migration place as that of xylene cyanol FF (Fig. 1). No $O$-gene product was found on the gel from group AB phenotype DNAs. Heterozygote $A O$ or $B O$ DNAs also showed $O$-gene product the same as the group $\mathrm{O}$ DNAs (Fig. 2). $O$-gene product amplified from group $O$ phenotype DNAs purified by Chelex-100 method was less in amount than those purified by SDS-proteinase K-phenol method (data not shown).

\section{DISCUSSION}

We developed a new simple method for the detection of $O$-gene by allele specific amplification. Our sense primer contained number 243 to 258 base sequence of $O$-gene cDNA reported by Yamamoto et al. (1990a) at the $3^{\prime}$ end. The antisense primer contained number 260 to 273 base sequence common to $A, B$, and $O$-gene cDNAs at the $3^{\prime}$ end. Our method uses a simple reaction mixture using a buffer system attached by Taq DNA polymerase manufacture and can detect the reaction product by polyacrylamide gel electrophoresis following non-isotopic silver staining. Our method requires only $4 \mathrm{hr}$ to obtain results starting from

\section{$\begin{array}{llllllllllllll}1 & 2 & 3 & 4 & 5 & 6 & 7 & 8 & 9 & 10 & 11 & 12 & 13 & 14\end{array}$}

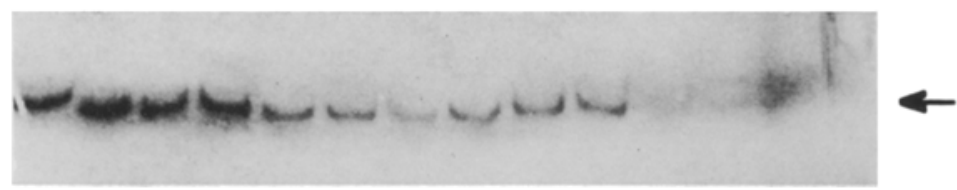

Fig. 1. Photograph showing the allere-specific amplification product of $O$-gene. Lanes $1-10$, group $\mathrm{O}$; lanes 11-14, group $\mathrm{AB}$. Arrow shows the position where $O$-gene product and xylene cyanole FF appear.

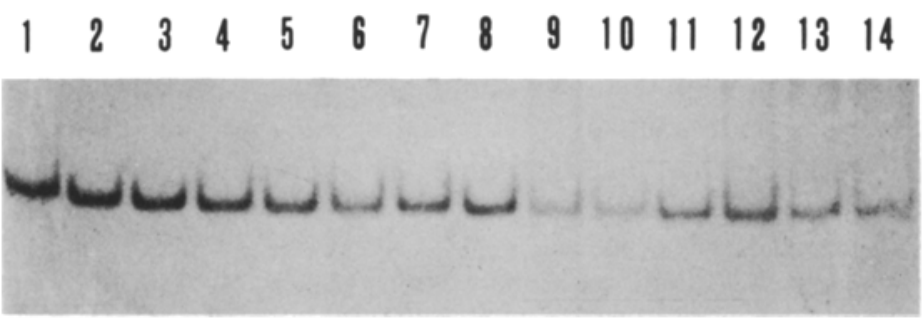

Fig. 2. Photograph showing the AS-PCR product of $O$-gene from heterozygote $A O$ or $B O$, and homozygote $O O D N A$. Lanes $1-3,8,12,13, A O$ genotype; lanes 4-6, 10, $11, B O$ genotype; lanes $7,9,14,0 O$ genotype. 
blood collection. When Chelex-100 method was carried out for preparation of genomic DNA, we can detect $O$-gene. However, the detected band from the DNA was weaker than that from the genomic DNA prepared by SDS-proteinase Kphenol method. This may be due to low concentration of the DNA and/or contamination of inhibitors of polymerase such as a heme-complex.

Ugozzoli and Wallace (1992) reported an allele specific PCR method. Their primers were overlapped at numbers $237-258$ bases for a sense primer and 257276 bases for an anti-sense primer from $O$-gene cDNA and they used a complex reaction mixture and a radioisotope for detection of the PCR product.

Yamamoto et al. (1990b) and Lee and Chang (1992) reported PCR-RFLP method. This method was used most popularly at this time. However, it needs two step enzyme reactions, namely, Taq DNA polymerase reaction and restriction enzyme digestion. These two step enzyme reactions make the PCR-RFLP a complicated method. Sometimes the second enzyme fails to digest the PCR product, and the method has a possibility of leading to a wrong conclusion.

PCR-denaturing gradient gel electrophoresis (PCR-DGGE) method (Johnson and Hopkinson, 1992) is a simple and good procedure for the detection of wide varieties of nucleotide base changes. However, preparation of the denaturing gradient gel is complicated and it takes $19 \mathrm{hr}$ for electrophoresis. Because of these reasons, PCR-DGGE method will hardly become popular.

The allele specific (AS)-PCR method we developed has advantages such as simplicity to detect a single base change, a requirement of small amount of DNA, and an easiness for detection of PCR products. However, this method also has a disadvantage that we cannot always deny a base change when we find no PCR product. Generally no AS-PCR product meant (1) no base change (mutation) at the detection point on the target DNA, (2) denatured or fragmented DNA, (3) a denatured polymerase or contamination of polymerase inhibitors, or (4) an equipment trouble.

Our method can be applied to small fragmented DNA because we amplified only 43 base pairs. Our genomic DNAs used in this study seemed to have enough base length for the AS-PCR, since the DNAs had at least 130 base pairs that were detected from $X$-chromosome specific sequence according to the method of Witt and Erickson (1989) (data not shown). In addition, no discrepancy was found between serologic analysis data to ABO blood group and the AS-PCR results in this study. These show that this method can clear problems mentioned above as far as we use adequate controls. Our method may be useful to not only paternity tests but also to criminal investigations. The application data will be published elsewhere in a forensic journal.

Acknowiedgments This study was supported in part by Grant-in-Aid for Scientific Research numbers 03670294 (to T.M.) and 01440038 (to K.F.) from the Ministry of Education, Science and Culture of Japan. 


\section{REFERENCES}

Budowle B, Chakraborty R, Giusti AM, Eisenberg AJ, Allen RC (1991): Analysis of the VNTR locus D1S80 by the PCR followed by high-resolution PAGE. Am J Hum Genet 48: 137-144

Hochmeister MN, Budowle B, Jung J, Borer UV, Comey CT, Dirnhofer R (1991): PCR-based typing of DNA extracted from cigarette butts. Int J Legal Med 104: 229-233

Johnson PH, Hopkinson DA (1992): Detection of ABO blood group polymorphism by denaturing gradient gel electrophoresis. Hum Mol Genet 1: 341-344

Lee JC, Chang J-G (1992): ABO genotyping by polymerase chain reaction. J Forensic Sci 37: 12691275

Race RR, Sanger R (1975): The ABO blood groups. In: Race RR, Sanger R (eds). Blood groups in man. Blackwell Scientific Publishing, Oxford, pp 8-91

Salmon C, Cartron J-P, Rouger P (1984): The ABO system. In: Salmon C, Cartron J-P, Rouger P (eds). The human blood groups. Masson Publishing \& Year Book Medical Publishers, Chicago, pp 94-140

Sambrook J, Fritsch EF, Maniatis T (1989): Isolation of DNA from mammalian cells. In: Sambrook J, Fritsch EF, Maniatis T (eds). Molecular cloning a laboratory manual. Cold Spring Harbor Laboratory Press, pp 9.16-9.19

Ugozzoli L, Wallace RB (1992): Application of an allele-specific polymerase chain reaction to the direct determination of $\mathrm{ABO}$ blood group genotypes. Genomics 12: 670-674

Witt M, Erickson RP (1989): A rapid method for detection of Y-chromosomal DNA from dried blood specimens by the polymerase chain reaction. Hum Genet 82: 271-274

Yamamoto F, Marken J, Tsuji T, White T, Clausen H, Hakomori S (1990a): Cloning and characterization of DNA complementary to human UDP-GalNAc: Fuc $\alpha 1 \rightarrow 2$ Gal $\alpha 1 \rightarrow 3$ Ga1NAc transferase (histo-blood group A transferase) mRNA. J Biol Chem 265: 1146-1151

Yamamoto F, Clausen H, White T, Marken J, Hakomori S (1990b): Molecular genetic basis of the histo-blood group ABO system. Nature 345: 229-233

Vol. 39, No. 3, 1994 